\title{
PERLINDUNGAN HAK-HAK TENAGA KERJA INDONESIA (TKI) YANG BEKERJA DI LUAR NEGERI
}

\section{Triyan Febriyanto}

Mahasiswa Fakultas Hukum, Universitas

Negeri Semarang

Surel: triyanfebriyan62@yahoo.com

\author{
Agus Taufiqur Rohman \\ Mahasiswa Fakultas Hukum, Universitas \\ Negeri Semarang \\ Surel: agustaufiqur7@gmail.com
}

\begin{abstract}
ABSTRAK
Untuk melindungi TKI yang bekerja di luar negeri (work in overseas), pemerintah telah menetapkan Undang- Undang Nomor 39 Tahun 2004 tentang Penempatan dan Perlindungan TKI di Luar Negeri dan peraturan pelaksa-naannya. Meskipun demikian TKI belum dapat terlindungi secara layak baik pada tahap pra penempatan (pre-placement), saat penempatan (during placement), dan setelah penempatan (post-placement). Berbagai kasus menimpa TKI yang bekerja di luar negeri seakan tidak mengenal kata akhir mulai dari tindakan kekerasan, pelecehan seksual, upah, jam kerja, dan waktu istirahat yang tidak sesuai dengan perjanjian kerja, dan lain-lain yang melanggar harkat dan martabat manusia.
\end{abstract}

RIWAYAT ARTIKEL

Article History

Diterima 20 Maret 2017

Dipublikasi 20 November 2018

\section{KATA KUNCI}

Keywords Tenaga Kerja Indonesia (TKI), Perlindungan, Hak Asasi Manusia,

\section{HOW TO CITE (saran perujukan):}

Febriyanto, T. \& Rohman, A.T. (2018). "Perlindungan Hak-Hak Tenaga Kerja Indonesia (TKI) Yang Bekerja di Luar Negeri", Lex Scientia Law Review. Volume 2 No. 2, November, hlm. 139-154 


\section{PENDAHULUAN}

Negara Indonesia merupakan negara yang kaya akan sumber daya manusia. Sayangnya sumber daya manusia yang dimiliki Indonesia kebanyakan bukan tenaga ahli karena latar belakang pendidikan yang kurang memadai. Dengan banyaknya sumber daya manusia yang ada, hal ini berbanding terbalik dengan lapangan kerja yang ada di Indonesia, sehingga banyak sekali pengangguran di setaiap kota. Padahal seperti yang diketahui, di dalam Undang-Undang Dasar Negara Republik Indonesia (UUD NRI) 1945 pada Pasal 27 ayat (3) menyatakan bahwa, tiap-tiap warga negara berhak atas pekerjaan dan penghidupan yang layak bagi kemanusiaan. Dengan mengacu undang-undang tersebut seharusnya setiap warga negara berhak mendapatkan pekerjaan sesuai untuk memiliki penghidupan yang layak sesuai dengan kebutuhannya (Adharinal,2012:158).

"In this era of globalization, the migration of people a cross the world were most increasingly. Migration is the right of person to move to other countries which guarantee by the international law of human rights as enshrined in the International Bill of Rights. The purpose of this basic rights is to improve development of economic, social and cultural life of those persons (Stephen James; 2007: 195). By the end of twentieth century's, the moral truth of human rights clearly recognized by the international community and often said that rest on a sympathetic identification of deep conscience of human being (Robert Meister; 2011 :20). Thus, the rights to gain job in other countries through migration mechanism may be deemed as a rights of persons to improve their economic life, actually can be said as universal human rights, since it is part of the "right to life" (Paulina Tambakaki, 2010: 8 dalam Diantha, 2015: 53)."

Dengan dasar alasan mendorong setiap individu untuk mendapatkan uang banyak dengan cara cepat, salah satunya adalah menjadi Tenaga Kerja Indonesia. Negara mempunyai tujuan untuk menyelenggarakan kesejahteraan umum atau negara melakukan tugas service public. Untuk menjalankan tugas service public ini negara bertindak atas kewenangan yang ada padanya, baik yang diatur dalam peraturan Perundang-undangan atau melalui campur tangan pemerintah (freies ermesen) dalam rangka mencapai tujuan Negara (Anggriani,2012: 88). Indonesia merupakan negara pengirim (sending country) buruh migran terbesar kedua di Asia Tenggara setelah Philipina. 1 Berdasarkan data yang adapada tahun 2009 jumlah TKI yang bekerja di luar negeri mencapai 6,5 juta orang. Secara makro uang yang dikirim (remittance) oleh buruh migran Indonesia pada tahun 2009 berjumlah US\$ 6,793

https://journal.unnes.ac.id/sju/index.php/Islr/

Copyrights (C) 2018. UKM Lex Scientia, Fakultas Hukum Universitas Negeri Semarang 
milyar, dan pada tahun 2010 diprediksi meningkat menjadi US\$ 7,139 milyar dollar (Adharinal,2012:161).

Salah satu daerah asal TKI yang cukup besar di Indonesia adalah NTB khususnya Pulau Lombok. Sampai dengan akhir tahun 2009 berdasarkan data pada Dinas Tenaga Kerja dan Transmigrasi Propinsi NTB jumlah TKI yang bekerja di luar negeri mencapai 650.000 orang. Remittance yang dikirim oleh TKI sebanyak Rp2.000.000.000,- (dua milyar rupiah) per hari belum termasuk yang dikirim lewat teman yang pulang atau yang dibawa langsung oleh TKI yang bersangkutan. Untuk melindungi TKI yang bekerja di luar negeri (work in overseas), pemerintah telah menetapkan Undang- Undang Nomor 39 Tahun 2004 tentang Penempatan dan Perlindungan TKI di Luar Negeri dan peraturan pelaksanaannya. Meskipun demikian TKI belum dapat terlindungi secara layak baik pada tahap pra penempatan (pre-placement), saat penempatan (during placement), dan setelah penempatan (postplacement). Berbagai kasus menimpa TKI yang bekerja di luar negeri seakan tidak mengenal kata akhir mulai dari tindakan kekerasan, pelecehan seksual, upah, jam kerja, dan waktu istirahat yang tidak sesuai dengan perjanjian kerja, dan lain-lain yang melanggar harkat dan martabat manusia.

Diundangkannya Undang-Undang Nomor 39 Tahun 2004 tentang Perlindungan Tenaga Kerja Indonesia di Luar Negeri, Tambahan Lembaran Negara Republik Indonesia Nomor 4445 Tahun 2004. diharapkan dapat memberikan perlindungan bagi para Tenaga Kerja Indonesia yang berada di Luar Negeri. Selain itu adanya Peraturan Menteri Tenaga Kerja Dan Transmigrasi No. 14/Men/2010 tentang Pelaksanaan Penempatan dan Perlindungan Tenaga Kerja Indonesia di Luar Negeri dan Peraturan Menteri Tenaga Kerja Dan Transmigrasi Republik Indonesia Nomor Per.07/Men/V/2010 Tentang Asuransi Tenaga Kerja Indonesia juga merupakan landasan hukum untuk melindungi Tenaga Kerja Indonesia yang berada di luar negeri. Terungkap data dari hasil pra survey pada tanggal 10 Desember 2014 dengan pegawai Disnakertrans, ada lebih dari 18\% warga kabupaten kediri menjadi Tenaga Kerja Indonesia di luar negeri, dan 5\% dari angka TKI tersebut adalah Tenaga Kerja Indonesia tidak berdokumen resmi atau disebut ilegal (Latupono,2011: 64).

Dengan menggunakan Penyaluran Tenaga Kerja Indonesia (PJTKI) yang ada di setiap kota, mereka berangkat dengan kemampuan bahasa untuk berkomunikasi di sana, keterampilan, dokumen-dokumen resmi dari PJTKI serta Keimigrasian. Penempatan TKI berdasarkan jumlah statistik yang dilakukan oleh Badan Nasional Penempatan dan Perlindungan Tenaga Kerja Indonesia (BNP2TKI) pada tahun 2006-2012 mencapai 3.998.592 orang (Adharinal,2012:164). Menjadi TKI merupakan sebuah fenomena yang biasa terjadi di beberapa wilayah di Indonesia. Fenomena tersebut merupakan dampak dari ketidaktersediaan lapangan kerja dan juga akibat dari pembangunan yang tidak merata di beberapa wilayah, khususnya di daerah pedesaan. Meski dengan dorongan sosiologis, latar belakang ekonomi serta 
kebijakan politik yang berbeda, Semenjak abad ke XIX tenaga kerja Indonesia telah tersebar hingga Suriname, New Caledonia, Siam dan Serawak dengan jumlah yang mencapai puluhan ribu pekerja yang bekerja sebagai kuli kontrak (Syafaat,2002: 1).

Terjadinya migrasi di Indonesia merupakan hal yang tidak dapat dihindari bagi negara yang sedang bersaing untuk menghadapi era globalisasi.2 Di Provinsi Jawa Timur pada tahun 2009 jumlah TKI yang berangkat ke luar negeri 46.418 orang; sementara pada tahun 2010 jumlah TKI yang berangkat ke luar negeri 53.815 orang. Di Nusa Tenggara Barat pada tahun 2008 TKI yang berangkat ke luar negeri 52.273 orang; sementara pada tahun 2009 TKI yang berangkat ke luar negeri 53.731 orang (Syafaat,2002: 29).

Jika kita dapat lihat masih banyak TKI di Indonesia yang mengalami perlakuan tidak menyenangkan oleh atasannya, bahkan banyak sekali TKI yang terancam dihukum mati yang pada faktanya pelanggaran-pelanggaran tersebut bukanlah sepenuhnya salah mereka. Dari kasus tersebut terlihat bahwa hak asai manusia orang lain masih kurang untuk dihargai padahal hak asasi manusia adalah hak yang melekat atau inherent pada diri manusia, yang berasal dari Tuhan sejak manusia itu dilahirkan. Dan negara Indonesia atau negara lain juga harus menghormati hak asasi manusia yang lain karena hak asasi manusia secara obyektif adalah kewenangan-kewenangan pokok yang melekat pada manusia sehingga harus dihormati oleh negara manapun (Widyawati,2008:41).

\section{Rumusan Masalah}

1. Bagaimana Hak-Hak Tenaga Kerja Indonesia Di Luar Negeri Berdasarkan UU No. 39 Tahun 2004 Tentang Penempatan Dan Perlindungan Tenaga Kerja Indonesia Di Luar Negeri?

2. Mengapa Peraturan Perundang Undangan Bagi Tenaga Kerja Indonesia di Luar Negeri Belum Dapat Melindungi HAK TKI Secara Layak Baik Secara Filosofis, Yuridis, Dan Sosiologis?

\section{Metode Penulisan}

Dalam penulisan makalah tentang "Perlindungan Hak-Hak Tenaga Kerja Indonesia (TKI) Yang Bekerja Di Luar Negeri" makalah ini menggunakan metode pengumpulan data atau kepustakaan (library research).

Menurut Koentjaraningrat teknik kepustakaan merupakan cara pengumpulan data bermacam-macam material yang terdapat diruang kepustakaan, seperti koran, buku-buku, jurnal, majalah, naskah, dokumen dan sebagainya yang relevan dengan penelitian (Koentjaraningrat, 1983: 420).

Menurut Sugiyono, studi kepustakaan berkaitan dengan kajian teoritis dan referensi lain yang berkaitan dengan nilai, budaya dan norma yang berkembang pada situasi sosial yang diteliti, selain itu studi kepustakaan sangat penting dalam 
melakukan penelitian, hal ini dikarenakan penelitian tidak akan lepas dari literaturliteratur Ilmiah (Sugiyono, 2012: 291).

Berdasarakan pengertian tersebut, maka penelitian tentang "Perlindungan Hak-Hak Tenaga Kerja Indonesia (TKI) Yang Bekerja Di Luar Negeri" menggunakan bermacam buku seperti buku, jurnal, koran, skripsi, dan sebagainya.

\section{PEMBAHASAN}

\section{A. Hak-Hak Tenaga Kerja Berdasarkan UU No. 39 Tahun 2004 Tentang Penempatan Dan Perlindungan Tenaga Kerja Indonesia Di Luar Negeri}

Pengaturan tentang penempatan tenaga kerja Indonesia ke luar negeri adalah Undang-undang No. 39 Tahun 2004 Tentang Penempatan Dan Perlindungan Tenaga Kerja Indonesia di Luar Negeri. Pada konsideran menimbang huruf c, d dan e, disebutkan bahwa tenaga kerja Indonesia di luar negeri sering dijadikan obyek perdagangan manusia, termasuk perbudakan dan kerja paksa, korban kekerasan, kesewenang-wenangan, kejahatan atas harkat dan martabat manusia serta perlakuan lain yang melanggar hak asasi manusia. Maka negara wajib menjamin dan melindungi hak asasi warga negaranya yang bekerja baik di dalam maupun di luar negeri berdasarkan prinsip persamaan hak, demokrasi, keadilan sosial, kesetaraan dan keadilan gender, anti diskriminasi dan anti perdagangan manusia. Dalam hal penempatan tenaga kerja Indonesia di luar negeri merupakan suatu upaya untuk mewujudkan hak dan kesempatan yang sama bagi tenaga kerja untuk memperoleh pekerjaan dan penghasilan yang layak, yang pelaksanaannya dilakukan dengan tetap memperhatikan harkat, martabat, hak asasi manusia dan perlindungan hukum serta pemerataan kesempatan kerja dan penyediaan tenaga kerja yang sesuai dengan kebutuhan nasional (Husni,2000: 54).

Berdasarkan ketentuan Pasal 27 ayat (2) jo. Pasal 28 D Ayat (2) UUD Negara RI Tahun 1945 jelaslah bahwa bekerja merupakan hak asasi warga negara yang merupakan tanggung jawab negara untuk memenuhinya. Untuk melaksanakan amanat konstitusi ini, pemerintah telah menetapkan berbagai kebijakan. Salah satunya adalah dengan mengisi peluang kerja di luar negeri. Indonesia adalah pengirim (sending country) buruh mengirim terbesar kedua di Asia Tenggara setelah Philipina (Naovalita,2016: 64). Berdasarkan data yang ada pada tahun 2009 jumlah TKI yang bekerja di luar negeri mencapai 6,5 juta orang, secara makro uang yang dikirim (remittance) oleh buruh migran Indonesia pada tahun 2009 berjumlah U\$\$ 6,793 milyar, dan pada tahun 2010 meningkat menjadi U\$\$ 7,139 milyar dollar (Husni,2000: 65). 
Mengatasi persoalan Tenaga Kerja Indonesia (TKI) yang bermasalah di luar negeri, tentu tidak lepas dari diplomasi yang harus dilakukan terhadap negara yang bersangkutan, untuk melakukan hal tersebut, dalam hal ini negara harus terlebih dulu memenuhi hak setiap warga negara Indonesia untuk memperoleh pekerjaan di dalam negeri. Ada hal-hal yang perlu disepakati terlebih dulu dimana hal yang paling penting adalah masalah hak asasi manusia. Hak asasi manusia bagi warga negara Indonesia yang akan bekerja ke luar negeri yang pertama-tama harus dipenuhi adalah hak untuk memperoleh pekerjaaan di dalam negeri. Karena kebijakan penghentian pengiriman TKI ke luar negeri atau moratorium itu seringkali ditentang karena alasan melanggar hak asasi manusia warga negara untuk bekerja di luar negeri. Meskipun ada konvensi mengenai free movement, tetap saja kita harus memperhatikan mengenai pemenuhan hak warga negara di dalam negeri untuk mendapatkan pekerjaan. Akar permasalahan TKI sebenarnya disebabkan oleh pengelola negara yang berifat swasta. Regulasi mengenai TKI itu rumusannya adalah peraturan penempatan dan perlindungan, dimana seolah-olah perlindungan TKI itu menjadi sub ordinat dari penempatan TKI. Menjadi prioritas itu adalah perlindungan terhadap TKI sejak dari calon TKI direkrut, diberangkatkan, ditempatkan, hingga pemulangan kembali ke keluarganya di tanah air. Harus ada pemilahan yang jelas antara peran dan tanggung jawab negara pengirim, negara penempatan dan individu TKI itu sendiri (Husni,2000: 65).

Menurut putusan MK No. 12/PUU-XIV/2016, dimana kasus ini menceritakan seorang tenaga kerja Indonesia yang meminta hak-hak mereka selama bekerja diluar negeri. Karena pada dasarnya banyaknya kasus dimana tenaga kerja Indonesia yang mengalami kasus kekerasan saat mereka bekerja diluar negeri. Hal inilah yang mendorong para pekerja menuntut pemerintah Indonesia untuk memenuhi hak-hak mereka.

Salah satu daerah asal TKI yang cukup besar di Indonesia adalah NTB khususnya pulau lombok. Sampai dengan akhir tahun 2009 berdasarkan data pada Dinas Tenaga Kerja dan Transmigrasi Provinsi NTB jumlah TKI yang bekrja di luar negeri mencapai 650.000 orang. Remittance yang dikirim oleh TKI sebanyak 2.000.000.000,- (dua milyar rupiah) per hari belum termasuk yang dikirim lewat teman yang pulang atau dibawa langsung oleh TKI yang bersangkutan (Burhanuddin,2007). Untuk melindungi TKI yang bekerja di luar negeri (work in overseas) pemerintah telah menetapkan Undang-Undang Nomor 39 tahun 2004 tentang penempatan dan perlindungan TKI diluar negeri dan peraturan pelaksanaanya.

Perlindungan TKI menurut Pasal 1 point (4) Undang-Undang Nomor 39 Tahun 2004 yang menjelaskan bahwa perlindungan tenaga kerja indonesia adalh segala upaya melindungi kepentingan calon Tenga Kerja Indonesia maupun Tenaga Kerja Indonesia dalam mewujudkan terjadinya pemenuhan hak-hak sesuai dengan peraturan perundang-undangan, baik sebelum, selama, maupun sesudah bekerja 
(Sukowati,2004: 24). Jadi perlindungan hukum adalah perbuatan yang diberikan kepada seseorang atas dasar peraturan perundangan yang berlaku agar seseorang itu terjamin hak-haknya, setelah seseorang itu melakukan kewajibannya, sehingga terwujud kesejahteraan dan kedamaian didalam pergaulan hidup masyarakat (Sukowati,2004: 24).

Dalam pemberian perlindungan hukum untuk TKI diatur di Undang-Undang Nomor 39 Tahun 2004 Pasal 77 yang menyatakan bahwa:

1. Setiap calon TKI atau TKI mempunyai hak untuk memperoleh perlindungan sesuai dengan peraturan perundnag-udangan

2. Perlindungan sebgaimana yang dimaksud pada ayat (1) dilaksnakan mulai dari penempatan, masa penempatan, sampai dengan purna penempatan (Sukowati,2004: 24).

Dari pasal diatas, menujukkan bahwa pemeritah memberikan perlindungan terhadpat TKI atau calon TKI bila terjadi permasalahan di luar negeri, adanya perwakilan di luar negeri dalam memberikan perlindungan terhadap TKI hal ini sesuai dengan Undang-Undang Nomor 39 tahun 2004 pasal 78 yang menyatakan bahwa:

1. Perwakilan Republik Indonesia memberikan perlindungan terhadap TKI di luar negeri sesuai dengan peraturan perundang-undangan serta hukun dan kebiasaan Internasional

2. Dalam rangka perlindungan TKI di luar negeri, pemerintah dapat menetapkan jabatan atas ketenagakerjaan pada perwakilan Republik Indonesia ntertentu.

3. Penugasan atas ketenagakerjaan sebagaimana yang dimaksud pada ayat (2) dilakukan sesuai dengan peratuan perundang-undangan (Sukowati,2004: 2425).

Adapun dasar hukum perlindungan Tenaga kerja Idonesia di luar negeri dilakukan oleh perwakilan Republik Indonesia. Sementara itu perlindungan hukum di luar negeri diberikan didasarkan pada Undang-Undang Nomor 39 Tahun 2004 pasal 80 yang menyatakan bahwa:

1. Pemberian bantuan hukum sesuai dengan ketentuan hukum peraturan perundang-undangan negara tujuan serta hukum dan kebiasaan Internasional.

2. Pembelaan atas pemenuhan hak-hak sesuai dengan perjanjian kerja dan peraturan perundang-undangn di negara TKI ditetapkan (Sukowati,2004: 25). 
Berdasarkan Undang-Undang Nomor 39 tahun 2004 Pasal 80 menunjukkan adanya perlindungan calon TKI maupun TKI. Perlindungan calon TKI dan TKI sesuai dengan langkah-langkah berikut:

1. Disnakertrans Kabupaten atau Kota daerah asal calon TKI melakukan seleksi tentang umur, pendidikan, kesehatan, baik fisik maun administratif. Bagi yang memenuhi syarat ditetapkan sebagai calon TKI dan akan disulurkan melalui PPTKIS untuk proses penempatan

2. Calon TKI menandatangani perjanjian penempatan dengan PPTKIS diketahiu ole Disnakertrans kabupaten kota atau kota setemapat.

3. Calon TKI dipastikan diikutkan dalam progam asuransi perlindungan TKI, sehingga apabila terjadi musibah atau kecelakaan calon TKI atau TKI mendapatkan santunan sesuai dengan ketentuan

4. Calon TKI mengikuti Pembelaan Akhir Pemberangkatan (PAP) sebelum keberangkatan luar negeri. Sehingga calon TKImampu memahami cara yang harus ditempuh apabila menghadapi permasalahan diluar negeri (Sukowati,2004: 25-26).

Menurut Badan Nasional Penempatan dan Perlindungan Tenaga Kerja Indonesia tahun periode 2016 dan 2017 ada lebih dari 25 negara yang memperkerjakan tenaga kerja Indonesia dapat dilihat di table berikut:

Tabel 1 Data Penempatan Tenaga Kerja Indonesia Berdasarkan Negara Tahun Periode 2016 dan 2017

\begin{tabular}{|c|c|c|c|c|c|c|c|c|c|c|c|c|c|c|}
\hline \multirow{3}{*}{ No } & \multicolumn{14}{|c|}{$\begin{array}{l}\text { PENEMPATAN TENAGA KERJA INDONESIA BERDASARKAN NEGARA } \\
\text { PERIODE } 2016 \text { dan } 2017 \text { ( s.d September) }\end{array}$} \\
\hline & \multirow{2}{*}{ NEGARA } & \multirow{2}{*}{\begin{tabular}{|c|}
2016 \\
Jan-Sept \\
\end{tabular}} & \multicolumn{10}{|c|}{2017} & \multicolumn{2}{|c|}{$\begin{array}{l}\text { Selisih } 20168 \\
2017\end{array}$} \\
\hline & & & Januari & Februari & Maret & April & Mei & Juni & Juli & Agust & Sept & Total & Jumlah & $T / N$ \\
\hline 1 & MALAYSIA & 66.164 & 5.692 & 6.395 & 7.943 & 5.481 & 6.727 & 7.084 & 10.473 & 8.713 & 6.945 & 65.453 & -711 & $T$ \\
\hline 2 & TAIWAN & 56.025 & 4.925 & 5.009 & 6.041 & 5.022 & 5.516 & 5.638 & 7.053 & 5.940 & 4.453 & 49.597 & -6.428 & $T$ \\
\hline 3 & HONG KONG & 10.795 & 3.487 & 5.528 & 4.546 & 4.257 & 6.268 & 3.904 & 2.429 & 2.131 & 1.909 & 34.459 & 23.664 & $\mathrm{~N}$ \\
\hline 4 & SINGAPORE & 12.486 & 1.077 & 1.033 & 1.367 & 1.154 & 1.109 & 840 & 784 & 1.078 & 1.162 & 9.604 & -2.882 & $T$ \\
\hline 5 & SAUDI ARABIA & 11.231 & 520 & 449 & 482 & 404 & 516 & 283 & 731 & 884 & 648 & 4.917 & -6.314 & $T$ \\
\hline 6 & BRUNEI DARUSSALAM & 6.156 & 457 & 467 & 640 & 633 & 749 & 629 & 569 & 732 & 391 & 5.267 & -889 & $T$ \\
\hline 7 & KOREA SELATAN & 4.952 & 274 & 104 & 270 & 519 & 260 & 225 & 478 & 279 & 355 & 2.764 & -2.188 & $T$ \\
\hline 8 & UNITED ARAB EMIRATES & 2.157 & 141 & 170 & 110 & 131 & 154 & 66 & 200 & 239 & 187 & 1.398 & -759 & $T$ \\
\hline 9 & QATAR & 1.007 & 68 & 135 & 160 & 85 & 68 & 26 & 130 & 149 & 99 & 920 & -87 & $T$ \\
\hline 10 & OMAN & 796 & 82 & 98 & 76 & 56 & 63 & 68 & 268 & 176 & 79 & 966 & 170 & $\mathrm{~N}$ \\
\hline 11 & KUWAIT & 646 & 55 & 67 & 87 & 91 & 213 & 148 & 129 & 100 & 68 & 958 & 312 & $\mathrm{~N}$ \\
\hline 12 & ITALY & 630 & 29 & 33 & 78 & 87 & 88 & 72 & 124 & 78 & 71 & 660 & 30 & $\mathrm{~N}$ \\
\hline 13 & TURKEY & 479 & 17 & 10 & 64 & 215 & 215 & 154 & 42 & 31 & 15 & 763 & 284 & $\mathrm{~N}$ \\
\hline 14. & JAPAN & 25 & 20 & 7 & 19 & 4 & 5 & 329 & 38 & 45 & 46 & 513 & 488 & $\mathrm{~N}$ \\
\hline 15 & UNITED STATES & 221 & 21 & 13 & 10 & 232 & 8 & 4 & 6 & 2 & 4 & 300 & 79 & $\mathrm{~N}$ \\
\hline 16 & MALDIVES & 108 & 3 & 15 & 30 & 47 & 28 & 13 & 28 & 7 & 10 & 181 & 73 & $\mathrm{~N}$ \\
\hline 17 & GERMANY & 108 & 0 & 1 & 1 & 17 & 38 & 43 & 33 & 20 & 14 & 167 & 59 & $\mathrm{~N}$ \\
\hline 18 & GABON & 39 & 0 & 3 & 0 & 70 & 66 & 1 & 50 & 25 & 7 & 222 & 183 & $\mathrm{~N}$ \\
\hline 19 & SOLOMON ISLANDS & 15 & 13 & 40 & 2 & 45 & 66 & 30 & 22 & 17 & 8 & 243 & 228 & $\mathrm{~N}$ \\
\hline 20 & DENMARK & 109 & 0 & 0 & 0 & 6 & 56 & 27 & 33 & 18 & 4 & 144 & 35 & $\mathrm{~N}$ \\
\hline 21 & ZAMBIA & 109 & 6 & 8 & 14 & 12 & 21 & 7 & 13 & 45 & 15 & 141 & 32 & $\mathrm{~N}$ \\
\hline 22 & BRAZIL & 99 & 35 & 54 & 42 & 4 & 0 & 0 & 0 & 1 & 0 & 136 & 37 & $\mathrm{~N}$ \\
\hline 23 & NEW ZEALAND & 91 & 0 & 0 & 72 & 62 & 0 & 0 & 0 & 3 & 0 & 137 & 46 & $\mathrm{~N}$ \\
\hline 24 & PAPUA NEW GUINEA & 8 & 1 & 0 & 29 & 41 & 28 & 10 & 47 & 11 & 27 & 194 & 186 & $\mathrm{~N}$ \\
\hline 25 & FRANCE & 10 & 3 & 2 & 0 & 126 & 56 & 0 & 0 & 0 & 0 & 187 & 177 & $\mathrm{~N}$ \\
\hline & LAINNYA & 979 & 73 & 100 & \begin{tabular}{|l|}
147 \\
\end{tabular} & \begin{tabular}{|l|}
428 \\
\end{tabular} & \begin{tabular}{|l|}
178 \\
\end{tabular} & 120 & \begin{tabular}{|l|}
146 \\
\end{tabular} & 132 & 125 & 1.449 & 470 & $\mathrm{~N}$ \\
\hline & TOTAL & 175.445 & \begin{tabular}{|l|}
16.999 \\
\end{tabular} & 19.741 & 22.230 & \begin{tabular}{|l|}
19.229 \\
\end{tabular} & \begin{tabular}{|l|}
22.496 \\
\end{tabular} & 19.721 & 23.826 & 20.856 & 16.642 & 181.740 & 6.295 & $\mathrm{~N}$ \\
\hline & CATATAN : & & & & & & & & 'Peric & ode Cetah & Tanggal & 10 oktober & & \\
\hline & $\mathrm{T}$ : JUMLAH PENEMPATAN TA & HUN 201 & MENGALAN & II PENURUI & NAN DIBAN & NDINGKAN & DENGAN T & AHUN 2016 & & & & & & \\
\hline & $\mathrm{N}$ : JUMLAH PENEMPATAN TA & HUN 20171 & MENGALAI & UI KENAIK & AN DIBAND & DINGKAN D & DENGAN TA & UHUN 2016 & & & & & & \\
\hline & & & & & & & & & & & & & & 8 \\
\hline
\end{tabular}




\section{B. Tinjauan Filosofis Peraturan Yang Belum Dapat Melindungi Hak TKI di Luar Negeri}

Keberlakuan filosofis (filosofischegeltung) suatu kaidah hukum jika mencerminkan cita hukum (Rechtidee) bangsa Indonesia sebagai nilai positif yang tertinggi (uberpositivenwerte) yakni Pancasila (Ali,2002: 76). Pancasila berkedudukan sebagai cita hukum (Rechtsidee) dalam kehidupan bermasyarakat, berbangsa, dan bernegara. Cita hukum menurut Rudolf Stammler adalah konstruksi pikir yang mengarahkan hukum pada cita-cita yang diinginkan oleh masyarakat (Stammler,1995: 129). Cita hukum berfungsi sebagai bintang pemandu (Leitstern) untuk mencapai apa yang dicita-citakan (Attamimi: 309 ). Dengan semangat, "Ketuhanan Yang Maha Esa", maka produk peraturan perundangan tentang penempatan TKI ke luar negeri, baik pranata hukumnya maupun penegakannya dan penyelenggaraan penempatan TKI ke luar negeri harus didasarkan pada nilai-nilai moral yang luhur. Karena itu perilaku yang mengeksploitasi TKI sejak prapenempatan, saat penempatan maupun purnapenempatan dengan dalih apa pun, baik atas nama ras maupun agama tidak dapat dibenarkan. Semangat, "Kemanusiaan yang adil dan beradab" pada prinsipnya ingin menempatkan manusia sesuai dengan harkatnya sebagai makhluk Tuhan yang Maha Esa. Kemanusiaan, berasal dari kata manusia yaitu mahkluk yang berakal budi, memiliki potensi fikir, rasa, karsa dan keyakinan dengan potensi yang dimilikinya menjadi makhlukyang mempunyai martabat dan derajat tinggi (Fauzi,2005: 99).

Semangat sila "Persatuan Indonesia", mengandung prinsip nasionalisme, cinta bangsa dan tanah air; menggalang terus persatuan dan kesatuan Bangsa. Nasionalisme adalah syarat mutlak bagi pertumbuhan dan kelangsungan hidup suatu bangsa dalam abad modern sekarang ini, sebab tanpa rasa nasionalisme suatu bangsa akan hancur terpecah-belah dari dalam. Nasionalisme Pancasila mengharuskan bangsa Indonesia menghilangkan penonjolan kesukuan, keturunan ataupun perbedaan warna kulit. Mengacu pada kerangka berpikir kefilsafatan sila ketiga Pancasila itu, maka keseluruhan proses penempatan TKI melalui peraturan perundangannya, seharusnya tetap mampu menumbuhkan semangat nasionalisme bangsa, tanpa harus memandang rendah bangsa lain. Dalam prinsip nasionalisme ini juga tersirat kewajiban TKI untuk menjaga nama baik bangsa dan negara dengan cara tidak melakukan kegiatan yang bertentangan dengan hukum negara tujuan.

Semangat sila "Kerakyatan yang dipimpin oleh hikmah kebijaksanaan dalam permusyawaratan/perwakilan", tidak lain adalah demokrasi dalam arti umum, yaitu pemerintahan dari rakyat, oleh rakyat, untuk rakyat. Hikmah kebijaksanaan dalam permusyawaratan berarti, bahwa tindakan bersama diambil setelah ada keputusan bersama. Melalui semangat sila keempat ini, maka peraturan perundang-undangan tentang penempatan TKI ke luar negeri tidak diperbolehkan mengurangi bahkan mematikan hak-hak politik TKI sebagai warga negara Indonesia. Karena itu hak

https://journal.unnes.ac.id/sju/index.php/lsIr/

Copyrights (c) 2018. UKM Lex Scientia, Fakultas Hukum Universitas Negeri Semarang 
untuk mengorganisir diri bagi TKI di luar negeri dalam rangka memberi penguatan hak-hak dasar bagi TKI mutlak harus memperoleh jaminan di dalam peraturan perundangan maupun dalam MoU yang dibuat dengan negara penempatan.

Semangat "Sila Keadilan Sosial Bagi Seluruh Rakyat Indonesia", menghendaki adanya kemakmuran yang merata di antara seluruh rakyat. Keadilan sosial berarti harus melindungi yang lemah, dan hal ini bukan berarti yang lemah lalu boleh tidak bekerja dan sekedar menuntut perlindungan, melainkan sebaliknya justru harus bekerja menurut kemampuan dan bidangnya.Perlindungan yang diberikan adalah untuk mencegah kesewenang- wenangan dariyang kuat untuk menjamin adanya keadilan dan pemerataan.

\section{Tinjauan Yuridis Peraturan Yang Belum Dapat Melindungi Hak TKI di Luar Negeri}

Kajian terhadap ketidakberlakuan secara yuridis suatu peraturan perundangundangan dapat dikaji dari derajat sinkroninasinya baik dengan peraturan di atasnya (vertikal) maupun dengan peraturan perundang-undangan lain yang sederajat (horisontal).

\section{a. Sinkronisasi Vertikal}

Sinkronisasi berasal dari kata sinkron artinya sejalan, sesuai, selaras. Dalam bahasa Indonesia istilah yang hampir sama maknanya dengan sinkron adalah harmoni yang dapat berarti keselarasan, kecocokan, keserasian. Namun demikian makna harmonisasi hukum lebih luas dari sinkronisasi. Sinkronisasi merupakan bagian dari kajian harmonisasi, namun sinkronisasi tidak dapat diaplikasikan dalam kajian norma dan sistem hukum global atau transnasional. Sinkronisasi peraturan perundang-undangan secara vertikal yang dikaji apakah suatu peraturan perundangundangan yang berlaku bagi suatu bidang kehidupan tertentu tidak saling bertentangan, apabila dilihat dari sudut hirarki perundang-undangan tersebut (Goesniadhie,2006: 24).

Dengan demikian kajian sinkronisasi vertical dalam tulisan ini adalah peraturan perundangan- undangan di bidang penempatan dan perlindungan TKI di luar negeri sesuai dengan teori hierarki norma hukum (Stufenbautheorie) dari Kelsen yang penjabarannyasebagaimana diatur dalam Undang-Undang Nomor 10 Tahun 2004 tentang Pembentukan Peraturan Perundang-undangan. Berdasarkan Pasal II Aturan Peralihan UUD 1945 yang menetapkan segala badan negara dan peraturan yang ada masih langsung berlaku, selama belum diadakan yang baru menurut Undang-Undang Dasar ini, maka aturan yang ada yang berkaitan dengan pengerahan orang Indonesia yang bekerja ke luar negeri yakni Ordonansi tentang Pengerahan Orang Indonesia untuk Melakukan Pekerjaan di Luar Negeri atau 
Werving van Indoneiersvoor het Verrichten van Arbeidbuiten Indonesia (Staatsblad Tahun 1887 Nomor 8) (Soepomo, 1983: 21).

\section{b. Sinkronisasi Horizontal (Harmonisasi)}

Dalam sinkronisasi horisontal yang dikaji adalah peraturan perundangundangan yang sederajat yang mengatur mengenai bidang yang sama. Bidang yang sama yang dimaksudkan adalah peraturan perundangan yang memiliki kesamaan pengaturan substansi atau memiliki relevansi dengan bidang yang dikaji. Peraturan perundang-undangan dimaksud dalam kaitannya dengan penempatan dan perlindungan TKI yang bekerja di luar negeri adalah:

1) Undang-Undang No. 39 Tahun 1999 tentang HAM

Undang-Undang Nomor 39 Tahun 2004 tentang Penempatan dan Perlindungan Tenaga Kerja Indonesia di Luar Negeri pada bagian konsideran menimbang menyebutkan bahwa (1) bekerja merupakan hak asasi manusia yang wajib dijunjung tinggi, dihormati, dan dijamin penegakannya, (2) Tenaga Kerja Indonesia di luar negeri sering dijadikan obyek perdagangan manusia, termasuk perbudakan dan kerja paksa, korban kekerasan, kesewenang-wenangan, kejahatan atas harkat dan martabat manusia, serta perlakuan lain yang melanggar hak asasi manusia.

2) Undang-Undang No. 32 Tahun 2004 tentang Pemerintahan Daerah

Otonomi daerah yang diatur dengan Undang-Undang Nomor 22 tahun 1999 jo. 32 Tahun 2004 tentang Pemerintahan Daerah menganut prinsip otonomi seluas-luasnya dalam arti daerah diberikan kewenangan untuk mengatur dan mengurus semua urusan pemerintahan di luar urusan yang merupakan kewenangan Pemerintah yakni politik luar negeri, pertahanan, keamanan, moneter, yustisi, dan agama. Daerah diberikan kewenangan membuat kebijakan dalam memberikan pelayanan, peningkatan peran serta, prakarsa, dan pemberdayaan masyarakat yang bertujuan untuk peningkatan kesejahteraan masyarakat.

Urusan pemerintahan yang bersifat pilihan adalah urusan pemerintahan yang diprioritaskan oleh pemerintahan daerah untuk diselenggarakan yang terkait dengan upaya mengembangkan potensi unggulan (core competence) yang menjadi kekhasan daerah. Khusus dalam bidang ketenagakerjaan yang merupakan fokus kajian ini, urusan wajib yang menjadi kewenangan pemerintahan daerah propinsi merupakan urusan dalam skala propinsi yang meliputi pelayanan bidang ketenagakerjaan lintas kabupaten/ kota (Pasal 13 huruf $h)$. 
Urusan wajib yang menjadi kewenangan pemerintahan daerah untuk kabupaten/kota merupakan urusan yang berskala kabupaten/kota yang meliputi pelayanan bidang ketenagakerjaan (Pasal 14 huruf h). Penjabaran lebih lanjut mengenai pembagian urusan ini diatur dalam Peraturan Pemerintah Nomor 38 Tahun 2007 tentang Pembagian Urusan Pemerintahan antara Pemerintah, Pemerintahan Daerah Provinsi, dan Pemerintahan Daerah Kabupaten/Kota (Bruggink,1996: 149).

\section{Tinjauan Sosiologis Peraturan Yang Belum Dapat Melindungi Hak TKI di Luar Negeri}

Keberlakuan empiris dapat dilihat dari perilaku hukum (legal behavior) warga masyarakat yang dikenai aturan hukum itu. Jika masyarakat berperilaku dengan mengacu pada keseluruhan kaidah hukum atau mentaati suatu kaidah hukum, maka terdapat keberlakuan faktual atau empiris kaidah itu. Atas dasar itu, maka kajian keberlakuan secara sosiologis atau empiris akan dimulai dari tingkat kesadaran hukum para pihak yang terlibat di dalamnya khususnya buruh migran (Bruggink, 1996: 156).

\section{a. Kurangnya Tingkat Kesadaran Hukum Calon TKI}

Kesadaran hukum merupakan kesadaran masyarakat untuk menerima atau menjalankan hukum sesuai dengan tujuan pembentukan hukum yang bersangkutan. Menurut Soerjono Soekanto kesadaran hukum merupakan konsepsi abstrak di dalam diri manusia tentang keserasian antara ketertiban dengan ketenteraman yangdikehendaki atau sepantasnya. Kesadaran hukum (legal awareness) memiliki beberapa indikator yakni pengetahuan tentang peraturan-peraturan hukum (law awareness), pengetahuan tentang isi peraturan-peraturan hukum (law acquaintance), sikap terhadap peraturan hukum (legal attitude) dan peri kelakuan hukum (legal behaviour) (Soekanto, 1992: 159).

\section{b. Kurangnya Pengawasan oleh Pegawai Pengawas Ketenagakerjaan}

Dalam Pasal 92 ayat (1) Undang-Undang Nomor 39 Tahun 2004 disebutkan bahwa pengawasan terhadap penyelenggaraan penempatan dan perlindungan TKI di luar negeri dilaksanakan oleh instansi yang bertanggung jawab di bidang ketenagakerjaan pada Pemerintah, Pemerintah Provinsi, dan Pemerintah Kabupaten/Kota. Sedangkan pengawasan terhadap penyelenggaraan penempatan dan perlindungan TKI di luar negeri dilaksanakan oleh Perwakilan Republik Indonesia di negara tujuan (Pasal 92 ayat (2)). 
Berdasarkan landasan normatif di atas, jelaslah bahwa pengawasan perburuhan/ketenagakerjaan yang dilakukan oleh pegawai pengawas dimaksudkan sebagai upaya preventif untuk menghindari terjadinya sengketa melalui pelaksanaan peraturan perundang-undangan ketenagakerjaan sebagaimana mestinya karena pengawasan merupakan langkah preventif untuk melaksanakan kepatuhan. Namun demikian, dalam bidang penempatan dan perlindungan TKI ke luar negeri pelaksanaan pengawasan ini tidak berjalan sebagaimana mestinya terbukti dengan adanya beberapa penyimpangan pelaksanaan perlindungan terhadap calon TKI yang dibiarkan begitu saja oleh pegawai pengawas. Tidak berjalannya pengawasan ini dengan baik karena terbatasnya sumberdaya dalam hal ini pegawai pengawas ketenagakerjaan dibandingkan dengan jumlah perusahaan yang harus diawasi. Berdasarkan data pada Dinas Tenaga Kerja dan Transmigrasi Propinsi NTB Tahun 2009 terdapat 7.176 unit perusahaan dengan tenaga kerja yang diserap mencapai 60.328 orang, sedangkan jumlah pegawai pengawas ketenagakerjaan hanya 14 orang. Jumlah ini masih jauh dari batas ideal satu pengawas mengawasi 20 unit perusahaan (Soekanto, 1992: 180).

\section{c. Penegakan Hukum (law enforcement) yang Lemah}

Undang-Undang Nomor 39 Tahun 2004 tentang Penempatan dan Perlindungan TKI di Luar, dalam Pasal 100 menyebutkan bahwa Menteri menjatuhkan sanksi administrative atas pelanggaran terhadap beberapa ketentuan sebagaimana dimaksud dalam Pasal 17 ayat (1), Pasal 20, Pasal 30, Pasal 32 ayat (1), Pasal 33, Pasal 34 ayat (3), Pasal 38 ayat (2), Pasal 54 ayat (1), Pasal 55 ayat (2) dan ayat (3), Pasal 58 ayat (1) dan ayat (2), Pasal 62 ayat (1), Pasal 67 ayat (1) dan ayat (2), Pasal 69 ayat (1), Pasal 71, Pasal 72, Pasal 73 ayat (2), Pasal 74, Pasal 76 ayat (1), Pasal 82, Pasal 83, atau Pasal 105 (Pasal 100). Sanksi administratif tersebut berupa peringatan tertulis, penghentian sementara sebagian atau seluruh kegiatan usaha penempatan TKI, pencabutan izin, pembatalan keberangkatan calon TKI, dan/atau pemulangan TKI dari luar negeri dengan biaya sendiri (Pasal 101) (Bruggink, 1996: 155). 


\section{KESIMPULAN}

Pengaturan tentang penempatan tenaga kerja Indonesia ke luar negeri adalah Undang-undang No. 39 Tahun 2004 Tentang Penempatan Dan Perlindungan Tenaga Kerja Indonesia di Luar Negeri. Pada konsideran menimbang huruf c, d dan e, disebutkan bahwa tenaga kerja Indonesia di luar negeri sering dijadikan obyek perdagangan manusia, termasuk perbudakan dan kerja paksa, korban kekerasan, kesewenang-wenangan, kejahatan atas harkat dan martabat manusia serta perlakuan lain yang melanggar hak asasi manusia. Maka negara wajib menjamin dan melindungi hak asasi warga negaranya yang bekerja baik di dalam maupun di luar negeri berdasarkan prinsip persamaan hak, demokrasi, keadilan sosial, kesetaraan dan keadilan gender, anti diskriminasi dan anti perdagangan manusia.

Dari uraian di atas, dapat ditarik simpulan bahwa ketidakberlakuan UndangUndang Nomor 39 Tahun 2004 tentang Penempatan dan Perlindungan TKI di Luar Negeri secara filosofis karena belum mencerminkan cita hukum (Rechtidee) bangsa Indonesia sebagai nilai positif yang tertinggi (uberpositivenwerte), yakni Pancasila khususnya sila kekedua "Kemanusiaan yang adil dan beradab", yang menempatkan manusia sebagai makhluk yang memiliki harkat dan martabat.

Secara yuridis peraturan perundang-undangan di bidang penempatan dan perlindungan TKI tidak sinkron secara vertikal maupun horizontal. Sedangkan secara sosiologis kurangnya tingkat kesadaran hukum calon TKI, kurangnya pengawasan dari pegawai pengawas ketenagakerjaan, penegakan hukum (law enforcement) yang lemah. Untuk melindungi TKI yang bekerja di luar negeri secara layak harus dimulai dengan melakukan pembaharuan hukum (legal reform) terhadap Undang-Undang Nomor39 Tahun 2004. Pembaharuan dimulai dari asas yang dijadikan landasan filsafati. Undang-undang yang dihasilkan perlu disosialisasikan dengan baik kepada semua stakeholders, dan dalam pelaksanaannya perlu dibarengi dengan penegakan hukum yang tegas. 


\section{DAFTAR PUSTAKA}

Adharinal. 2012. Perlindungan Terhadap Tenaga Kerja Indonesia Irregular Di Luar Negeri (Protection of Irregular Indonesian Workers In Overseas. Jurnal Rechtvinding. Vol. 1 No. 1 Januari-April 2012.

Ali, Achmad. 2002. Menguak Tabir Hukum (Suatu Kajian Filosofis dan Sosiologis). Gunung Agung. Jakarta.

Anggriani, Jum.2012. Hukum Administrasi Negara. Graha Ilmu. Yogyakarta.

Attamimi, Hamid. Peranan Keputusan Presiden RI dalam Penyelenggaraan Pemerintahan Negara (Suatu Studi Analisis Mengenai Keputusan Presiden yang Berfungsi Pengaturan dalam Kurun Waktu Pelita $I-I V$ ). Disertasi. Universitas Indonesia. Jakarta.

Diantha, I Made Pasek. Protecting Migrant Workers An Indonesian Experiences. International Journal of Business, Economics and Law. Vol. 7. Issue 3 August 2015.

Faiuzi, Achmad. 2005. Pancasila Tinjauan dari Konteks Sejarah, Filsafat, Ideologi Nasional dan Ketatanegaraan Republik Indonesia. Danar Wijaya Brawijaya University Press. Malang.

Goesniadhie, Kusnu. 2006. Harmonisasi Hukum dalam Perspektif Perundang-undangan. JP Books. Surabaya.

Husni, Lalu. 2000. "Pengantar Hukum Ketenagakerjaan Indonesia”. Raja Grafindo Persada. Jakarta.

Latupono, Barzah. Perlindungan Hukum Dan Hak Asasi Manusia Terhadap Pekerja Kontrak (Outsourcing) Di Kota Ambon. Jurnal Sasi. Vol. 17 No. 3 Bulan Juli-September 2011.

Mertokusumo, Sudikno. 1991. Mengenal Hukum. Liberty. Yogyakarta.

Naovalita, Tita. 2016. "Perlindungan Sosia Buruh Migran Perempuan". Jakarta Soepomo, Iman.1983. Pengantar Hukum Perburuhan. Djambatan. Jakarta.

Soekanto, Soerjono. 1992. Kesadaran Hukum dan Kepatuhan Hukum. Rajawali Jakarta.

Sukowati, Sunawar. "Perlindungan Tenaga Kerja Indonesia (TKI) ke Luar Negeri menurut Undang-Undang Nomor 39 Tahun 2004 tentang Penempatan dan Perlindungan Tenaga Kerja Indonesia”. Semarang: Sekripsi Universitas Negeri Semarang.

Stammler, Rudolf. Theo Hujbers Filsafat Hukum dalam Lintasan Sejarah. Kanisius. Yogyakarta.1995.

Widyawati, Anis. "Kajian Hukum Internasional Terhadap HAM". Jurnal Ilmu Hukum Pandecta. Vol 2. No 2. Juli-Desember 2008. 


\section{Alterum Non Laedere}

\section{Perbuatanmu janganlah merugikan orang lain}

